\title{
CORPOREIDADE E GÊNERO EM REVISTAS BRASILEIRAS DE CIÊNCIAS HUMANAS (2008-13): LIMITES E CONTRIBUIÇÕES AO DEBATE SOBRE POVOS INDÍGENAS A PARTIR DO CASO TEMBÉ-TENETEHARA
}

\author{
CAMILLE GOUVEIA CASTELO BRANCO BARATA ${ }^{1}$ \\ $U F P A$
}

JANE FELIPE BELTRÃO ${ }^{2}$

$U F P A$

\begin{abstract}
RESUMO:O trabalho realiza uma revisão bibliográfica acerca da discussão sobre a questão do corpo compreendida nos estudos de gênero no Brasil, e problematiza em que medida a produção sobre o tema focaliza os povos indígenas em suas análises, considerando a importância dos coletivos etnicamente diferenciados na literatura antropológica. Para esse fim, realiza-se um levantamento bibliográfico em três dos mais importantes periódicos brasileiros qualificados nas últimas avaliações (2010/2013) pela Coordenação de Aperfeiçoamento de Pessoal de Nivel Superior (CAPES): Estudos Feministas, Cadernos Pagu e Horizontes Antropológicos. Por fim, analisa-se como a corporeidade se constrói entre mulheres tembétenetehara a partir das pesquisas realizadas em diálogo com esse povo. Tem-se em vista a centralidade do corpo entre povos indígenas e o restrito uso da categoria gênero quando se trabalha entre esses povos.
\end{abstract}

PALAVRAS-CHAVE: povos indígenas; gênero; corporeidade; mulheres tembé-tenetehara; revisão bibliográfica.

ABSTRACT: This work performs a bibliographic review about a discussion about the question of body, understood in studies about gender in Brazil and problematizes the extent to which production about the theme focuses the indigenous people in their analysis, considering the importance of collective ethnically differentiated in the anthropological literature. For this end, realize a bibliographical survey in the three most importat Brazilian periodicals qualified in the last evaluations (2010/2013) for CAPES (Coordination of Improvement of Higher Education Personnel): Estudos Feministas, Cadernos Pagu and Horizontes Antropológicos.Ultimately, analyze how the corporeity is building between tembé-tenetehara women, starting in survey conduct in dialogue which this nation.In the view the centrality of the

\footnotetext{
${ }^{1}$ Graduanda em Ciências Sociais pela Universidade Federal do Pará (UFPA), bolsista de iniciação científica do CNPq e membro do grupo de pesquisa Cidade, Aldeia \& Patrimônio, ambos sob orientação da Professora Jane Felipe Beltrão. E-mail: camillecastelobranco@gmail.com .

${ }^{2}$ Antropóloga e historiadora, docente associada à Universidade Federal do Pará (UFPA) atuando nos programas de pós-graduação em Antropologia e Direito. Bolsista de produtividade em pesquisa do CNPq e líder do grupo de pesquisa Cidade, Aldeia \& Patrimônio. E-mail: janebeltrao@gmail.com .
}

Espaço Ameríndio, Porto Alegre, v. 8, n. 2, p. 11-48, jul./dez. 2014. 
body between indigenous peoples and the restricted use of gender when working among these people.

KEYWORDS: indigenous people; gender; corporeity; tembé-tenetehara women; bibliographical survey.

O presente artigo consiste em uma revisão bibliográfica acerca da discussão sobre a questão do corpo compreendida nos estudos de gênero no Brasil e problematiza em que medida a produção sobre o tema focaliza os povos indígenas em suas análises, considerando a importância dos coletivos diferenciados na literatura antropológica. Para esse fim, realiza-se um levantamento bibliográfico em três dos mais importantes periódicos brasileiros qualificados nas últimas avaliações (2010/2013) da Coordenação de Aperfeiçoamento de Pessoal de Nível Superior (CAPES): Estudos Feministas, Cadernos Pagu e Horizontes Antropológicos. O recorte temporal estabelecido vai de 2008 até 2013, tendo em vista a centralidade do corpo entre povos indígenas e o restrito uso da categoria gênero quando se trabalha entre povos etnicamente diferenciados. Os desdobramentos metodológicos baseiam-se nas formulações de Neves (2003), que, ao refletir sobre as limitações da resenha bibliográfica, afirma:

[a] produção de resenha [revisão] configura-se como gênero de literatura acadêmica, cujo princípio referenciador é contraditório, ainda mais se o acervo da literatura em pauta é extenso e ultrapassa campos intelectuais específicos. Ao mesmo tempo em que a construção da resenha deve conter pretensões de inclusão extensiva, deve, sob pena de perda de inteligibilidade ou redução ao simples levantamento bibliográfico, ser classificatória, excludente e arbitrária. As necessárias subdivisões e opções temáticas pressupõem reducionismos em relação à contribuição dos autores. Contudo, permitem uma melhor compreensão das associações e das perspectivas recorrentes [...] (NEVES, 2003, p. 77).

Embora não se pretenda, para os fins desse trabalho, realizar uma resenha bibliográfica, as orientações metodológicas da autora norteiam 
o levantamento, a revisão e a crítica feita à bibliografia analisada. Além das arbitrariedades e contradições estruturantes apontadas por Neves (2003), cabe ressaltar que o estabelecimento do recorte e a problematização dos resultados, no trabalho, não são aleatórios, uma vez quese coadunam com nosso objeto de pesquisa, que pretende, por meio do enfoque dos estudos de gênero, analisar a dimensão da corporeidade entre as mulheres da etnia Tembé-Tenetehara, inserindose no projeto Indígenas e quilombolas mulheres em situação de violência: diversidade sociocultural, Direitos Humanos e Políticas Públicas na Amazônia ${ }^{3}$, com o objetivo de verificar como a corporeidade diz do gênero, especialmente em situações de violência nos coletivos etnicamente diferenciados.

O segundo objetivo norteador da análise leva em conta que a Cadernos Pagu e a Estudos Feministas são referências nacionais na abordagem sobre gênero e sexualidade, e que Horizontes Antropológicos é um periódico reconhecido na área da Antropologia e das Ciências Sociais. As publicações focalizadas permitem circunscrever - ainda que parcialmente - as intervenções (ou omissões) teóricoepistemológicas no que tange à interseção entre gênero e etnia na construção da corporalidade entre povos indígenas, em diálogo com a pesquisa sobre corporeidade entre mulheres tembé-tenetehara.

$\mathrm{O}$ trabalho divide-se em quatro partes:

(1) Abordagem das perspectivas teóricas que se adotam na pesquisa sobre mulheres tembé-tenetehara, com vistas a contribuir à discussão do tema no caso de indígenas mulheres ${ }^{4}$;

(2) Discussão dos resultados e problematização alcançada por revista. Pretende-se mostrar em termos quantitativos qual a produção sobre gênero e corpo em cada um dos seis anos selecionados, quais as principais abordagens sob as quais o corpo foi tematizado e quais aportes

\footnotetext{
3 Financiado via Chamada MCTI/CNPq/SPM-PR/MDA Nº 32/2012 do Conselho Nacional de Desenvolvimento Científico e Tecnológico (CNPq). Em andamento sob a coordenação de Jane Felipe Beltrão.

4 Usa-se "indígenas mulheres" para enfatizar a especificidade do lugar de enunciação das protagonistas.
} 
teóricos foram utilizados. Ao fim da sessão, discute-se sobre os trabalhos que analisaram o corpo no caso dos povos indígenas;

(3) Discussão sobre como a corporeidade se constrói entre mulheres tembé-tenetehara, especialmente em situação de violência;

(4) A última sessão destina-se às considerações finais.

Corporeidade e Gênero: limites, deslocamentos e tensões teórico-
epistemológicas

Dizer da história do corpo é o mesmo que dizer da história da vida (SANT'ANNA, 2004, p. 03).

A revisão bibliográfica acerca das questões de gênero, etnicidade e corporeidade foram fundamentais para a estruturação do olhar perante as situações vivenciadas em campo e para o exercício da escuta etnográfica no diálogo com as interlocutoras. Dialogar com as visões sobre o tema da pesquisa e cotejá-las com as narrativas de mulheres tembé-tenetehara permitiu perceber nuances e compreender dinâmicas, procurando evitar a violência epistêmica no encontro - sempre tenso entre categorias antropológicas e nativas.

A revisão teórica também permitiu vislumbrar limites e tensões que envolvem a temática, o que levou à busca de alternativas teóricoepistemológicas que melhor auxiliassem na tessitura da investigação etnográfica junto às interlocutoras. Por fim, a procura pelos aportes teóricos que disciplinariam e condicionariam o olhar em campo trouxe à tona a desproporção da produção sobre gênero e corporeidade de povos indígenas em relação a outros sujeitos e coletivos na literatura antropológica, como se verá à frente. Portanto, a revisão a seguir embora seja de pequeno alcance e não tenha a pretensão de esgotar o tema, ainda em construção - visa incitar o debate e abrir caminho para o aprofundamento de investigações futuras. 
$\mathrm{O}$ entendimento acerca da corporeidade entre indígenas mulheres perpassa pelo confronto com a perspectiva que reflete sobre o corpo e a corporeidade a partir da oposição dualista e hierárquica entre natureza/cultura, corpo/espírito, homem/mulher. Essa perspectiva entende o corpo como mero receptáculo, onde as marcas culturais se inscrevem. O avançar da discussão sobre corporeidade no âmbito das ciências humanas tem demonstrado que tais oposições são insuficientes para compreender o lugar do corpo em múltiplas vivências culturais e epistemologias, conforme demonstra Maluf (2001).

Compreendido como modelo explicativo eminentemente ocidental, o dualismo, quando transposto para o contexto específico dos povos indígenas, constitui uma violência ontológica que impossibilita contemplar as diferentes perspectivas de mundos diversos (COSTA, 2014). Outra questão controversa reside no fato de que o modelo dualista frequentemente contribui para a opressão das mulheres, relegando-as ao espaço da emoção, do corpo e da irracionalidade, enquanto homens supostamente habitariam o espaço da razão, do espírito e da abstração, conforme pontua Grosz (2000).

Além do exposto, a polarização binária homem-mulher foi alvo de críticas severas no contexto dos estudos de gênero (BUTLER, 2003), na medida em que silencia e violenta outras subjetividades e performances que não se encaixam nessa disposição. Sobre a crítica feminista ao dualismo natureza/cultura, as considerações de Butler (2001) são particularmente elucidativas:

[a] relação entre cultura e natureza, pressuposta por alguns modelos do gênero como construção, supõe uma cultura ou uma agência do social que age sobre uma natureza, a qual é, ela própria, pressuposta como uma superfície passiva, fora do social, mas sua necessária contraparte. Uma questão que as feministas têm levantado é, pois, a de saber se o discurso que descreve a ação da construção como uma espécie de impressão ou imposição não seria taticamente masculinista, enquanto a figura da superfície passiva esperando aquele ato de penetração pelo qual o significado é atribuído não seria, taticamente, ou talvez - bastante obviamente feminino. Estará o sexo para o gênero assim como o feminino está para o masculino? (BUTLER, 2001, p. 154). 
As formulações teóricas que demonstram maior adequação ao que se pretende na pesquisa são aquelas elaboradas por Csordas (1990), especialmente no que tange ao conceito de embodiment, que propõe um novo paradigma nos estudos da corporeidade, segundo o qual o corpo é pensado como "sujeito da cultura", como a "base existencial da cultura", dotado de agência própria. Não apenas como receptáculo de símbolos culturais, mas como produtor de sentido, uma entidade social experiencial, atuante e interpretadora.

O recorte permite partir do pressuposto de que os contextos etnicamente diferenciados produzem perspectivas simbólico-culturais acerca do corpo, que são, também, diversas. Os corpos de indígenas mulheres carregam marcas indeléveis, visíveis ou não para pessoas não indígenas, que se relacionam de modo profundo com a estética, a cosmologia, os valores e as hierarquias presentes em seus contextos étnicos ${ }^{5}$. Tais dimensões são agenciadas por estas protagonistas a partir de seus lugares de fala e marcadores sociais da diferença, que são utilizados para "[...] explicar como são constituídas socialmente desigualdades e hierarquias entre grupos sociais e indivíduos" (PEREIRA e RODRIGUES, 2010, p. 159).

No que tange às articulações entre gênero e corporeidade, Butler (2001) considera a importância dos marcadores sociais da diferença na condução das abordagens sobre o corpo, uma vez que esses eixos de diferenciação atuam na própria materialização dos corpos. Se, conforme afirmam Seeger, DaMatta e Viveiros de Castro (1979), analisar a corporeidade entre os povos indígenas "é básico", cabe uma discussão mais detida sobre a produção antropológica a respeito do tema.

Mauss (1974) ocupa lugar pioneiro na análise antropológica do corpo, a partir de sua sistematização do que denomina técnicas corporais. Seu trabalho propõe que não há um comportamento natural em relação ao corpo e que a conversão em sujeito social implica em certa aprendizagem corporal. Passa a ser interesse da Antropologia a compreensão "[...] [d]as maneiras pelas quais os homens, de sociedade a

\footnotetext{
${ }^{5}$ Entende-se a categoria etnia a partir das considerações de Barth (2000), para quem os grupos étnicos devem ser reconhecidos a partir da fronteira que estabelecem em relação aos demais grupos, fronteira criada em face das diferenças identificadas pelos próprios membros do grupo em relação aos outros. Tais diferenças, portanto, estão imersas em relações de alteridade.
} 
sociedade, de uma forma tradicional, sabem servir-se de seu corpo" (MAUSS, 1974, p. 401).

Seeger, DaMatta e Viveiros de Castro (1979) consideram que a noção de pessoa entre os povos indígenas reporta-se à consideração da corporalidade enquanto idioma simbólico, que passa a ser pré-requisito à compreensão da organização social, da cosmologia e das formas de lidar com a natureza dos agentes sociais. O corpo insere e forma a pessoa na sociocosmologia de cada povo, pessoa essa que é definida nas sociedades indígenas a partir de uma pluralidade de níveis, estruturados internamente.

Nimuendajú (1956), em sua obra clássica sobre os Apinayé, demonstra a preparação e o aparato corporal em torno da primeira menstruação feminina, que inclui uma dieta especial que se estende ao marido, a proibição de se coçar com os dedos, se enfeitar, tomar parte nas danças e de ter relações sexuais com os homens, que se tornariam fracos e pálidos a partir de então. A preparação do corpo para o casamento também é descrita pelo autor, bem como a percepção, por parte desse povo, de que as plantas e frutos oriundos da roça seriam "filhos" dos indígenas, que precisariam ser cuidados e protegidos, dimensão que reestrutura a própria hierarquia entre humanidade e natureza.

DaMatta (1976), também sobre os Apinayé, demonstra o caráter processual de transformação da criança em pessoa humana, construída a partir das bases da cultura do povo, evitando a possibilidade de, em função da falta de sangue, a alma da criança deixar o corpo, o que implicaria na perda da vida. Os Apinayé consideram que o corpo é dividido em várias partes e é sempre desenhado de cima pra baixo, começando pela cabeça até os órgãos genitais. O corpo humano seria estruturado a partir da analogia com os animais caçados e esquartejados pelos indígenas.

Rosa (2008), que realizou estudo entre os Kaingang, afirma que o corpo é entendido não somente como suporte identitário, mas como lugar que articula significações sociocosmológicas que sobrepõem corpo e sujeito indígena. O corpo se faz por meio de processos de socialização que incorporam os valores e símbolos culturais do povo, mediando a relação do sujeito com os ambientes de vida. 
Cohn (2000) demonstrou que entre os Xicrin a criança nasce constituída por in (corpo) e karon, que se aproxima da noção de alma. $\mathrm{O}$ corpo das crianças recém-nascidas é considerado frágil e endurece com o tempo, a partir da pele. Enquanto esse endurecimento não ocorre, a criança corre o risco de perder o karon, principalmente quando está zangada ou sonhando. As intervenções sobre o corpo da criança visam, portanto, desenvolver a capacidade sensorial e os órgãos internos.

Do ponto de vista teórico, a pesquisa abre a possibilidade de circunscrever as relações de gênero entre os povos indígenas tendo a corporalidade como uma chave relevante para o entendimento dessa questão. Nesse sentido, o corpo não é visto como mero suporte das identidades sociais e sim como matriz de símbolos e objeto de pensamento (SEEGER, DAMATTA e VIVEIROS DE CASTRO, 1979) que opera na construção de significados sobre gênero.

Compreende-se, portanto, que a cultura é corporificada e que o corpo é significado e significante, construído e construtor de práticas, discursos e noção de pessoa. No caso das indígenas mulheres, o corpo vem à cena tanto como território de lutas e afirmações identitárias quanto como alvo de violências e estigmas. Nesse sentido, os saberes e fazeres em relação ao corpo produzem e deslocam significados sobre o "ser mulher", o "ser indígena" e vice-versa vivenciados pelas interlocutoras da etnia Tembé-Tenetehara, de acordo ou não com a proximidade que mantêm com os não indígenas.

A discussão sobre marcadores sociais da diferença conduz à questão da viabilidade de utilizar a categoria gênero para a análise em contextos etnicamente diferenciados. Atentando à crítica que afirma que gênero é uma intervenção ocidental e colonial no universo indígena (LUCIANO, 2006), propõe-se a utilização da categoria reconhecendo suas limitações e associando-a a outras perspectivas analíticas que, articuladas e confrontadas com os depoimentos das interlocutoras, permitem conduzir a discussão de forma mais adequada.

Primeiramente, entende-se que a categoria se relaciona com as reflexões de Scott (1995), para quem gênero é: (1) um elemento constitutivo das relações sociais baseadas nas diferenças percebidas entre os sexos e (2) uma forma primária de dar significado às relações de poder. A partir de Scott (1995), o termo ganha status de categoria 
analítica, de instrumento metodológico para o entendimento da construção, da reprodução e das mudanças das identidades de gênero. A autora assevera que tal categoria deve ser analisada sob um ponto de vista relacional, tendo em vista a especificidade dos contextos nos quais que se constrói. Tais formulações permitem dar um passo inicial no sentido de evitar essencializações homogeneizantes sobre os povos indígenas.

Nesse sentido, concorda-se com Mccallun (2013), para quem o uso da categoria "gênero" entre povos indígenas, quando devidamente controlado etnograficamente, rende "bons frutos". Segundo a autora, a real violência epistêmica consiste em reproduzir a dicotomia que opõe tradição e modernidade. Tal dicotomia pressupõe uma cultura objetificada e estagnada no tempo, em vias de extinção pela exposição aos valores modernos. A reprodução de tal dicotomia desconsidera que as culturas indígenas estão abertas à mudança e criatividade. O desafio acadêmico exposto aponta para a necessidade de proceder ao controle das dificuldades de tradução etnográfica, dos etnocentrismos ocidentais e do viés colonial vigente.

A necessidade de analisar as relações de gênero atentando para o contexto etnicamente diferenciado das mulheres tembé-tenetehara conduz à adoção da perspectiva interseccional proposta por Brah (2006) e McClintock (2010). Avtar Brah (2006) operacionaliza o conceito de "interseccionalidade" por meio da noção de "diferença" como categoria analítica, tomando diferença de modo não essencial, mas como categoria que remete à designação de "outros", a fim de estudar "as inter-relações das várias formas de diferenciação social, empírica e historicamente, mas sem necessariamente derivar todas elas de uma só instância determinante" (BRAH, 2006, p. 331-332), tentando evitar o perigo do "reducionismo". McClintock (2010) toma classe, "raça" e gênero como campos articulados da experiência, e não isolados uns dos outros ou simplesmente justapostos, mas que existem concretamente em e através de relações com cada um dos outros.

Assume-se, portanto, que a presença do marcador étnico afeta de forma reiterativa as trajetórias e lugares de fala das interlocutoras com as quais se dialoga, fazendo com que vivenciem preconceitos e discriminações de forma peculiar. Outros marcadores, como geração e 
classe, também podem inserir nuances importantes para a análise das situações para as quais se volta o olhar. Desse modo, analisar a especificidade do lugar de enunciação de indígenas mulheres a partir do entrecruzamento de múltiplos eixos de diferenciação passa a ser palavra de ordem e desafio acadêmico hoje, especialmente considerando que as interlocutoras "trabalham" a pauta dos povos indígenas - território, educação e saúde - tendo como referentes das demandas questões que lhes afetam cotidianamente em razão das interfaces com pessoas não indígenas do entorno: próximo e distante.

Por fim, as fundamentações teóricas propostas por Lugones (2008) explicitam o entendimento de que não se pode analisar a situação de mulheres de cor ${ }^{6}$ (incluindo indígenas mulheres) sem que se considerem as vicissitudes do processo histórico e violento de dominação colonial, que inclui o que a autora denomina como sistema moderno e colonial de gênero. Sistema este que se traduz pela brutalização, subordinação e desumanização de mulheres não brancas. Ainda segundo a autora, a colonização branca e ocidental cooptou homens de cor, o que resulta na colaboração desses agentes para debilitar o poder das mulheres.

As considerações de Lugones (2008) remetem às de Segato (2003), pois, de acordo com a autora, ao replicar a linguagem do dominador, o agente subalternizado a desloca, desgasta e desestabiliza, erodindo a própria dialética dominador-dominado e introduzindo uma marca de insubordinação. Assume-se que as percepções de Segato (2003) são elucidativas das possibilidades de agência - aqui utilizada no sentido atribuído por Bourdieu (1977) e Giddens (1984) - de sujeitos subalternizados, frente a relações de poder assimétricas. Ter em vista as diversas formas de exercício da agência permite compreender essas relações de forma mais nuançada.

Pacheco de Oliveira (1998) afirma, nesse sentido, que, à imposição das normas dominantes, segue-se a apropriação local,

\footnotetext{
${ }^{6}$ Nas palavras da autora: "[n]o se trata simplemente de un marcador racial, o de una reacción a la dominación racial, sino de un movimiento solidario horizontal. Mujeres de color es una frase que fue adoptada por las mujeres subalternas, víctimas de dominaciones múltiples en los Estados Unidos. «Mujer de Color» no apunta a una identidad que separa, sino a una coalición orgánica entre mujeres indígenas, mestizas, mulatas, negras: cherokees, puertorriqueñas, sioux, chicanas, mexicanas, pueblo, en fin, toda la trama compleja de las víctimas de la colonialidad del género. Pero tramando no como víctimas, sino como protagonistas de un feminismo decolonial" (LUGONES, 2008, p. 75).
} 
sempre específica e individualizadora, para os povos indígenas. $\mathrm{O}$ autor acrescenta que a atualização e a mudança histórica a partir da colonialidade não anulam as identidades étnicas, mas pelo contrário, as reforçam a partir da fronteira da alteridade. O autor ainda assevera a necessidade de abandonar perspectivas que refletem sobre os povos indígenas tendo $\mathrm{O}$ isolamento como comprovação da autenticidade étnica. A autenticidade é vista como gueto criado para satisfazer o mundo dominante e pouco contribui para a reflexão sobre o caráter dinâmico e não estrutural da cultura, conduzindo, inclusive, às armadilhas da exotificação, ao radicalizar a diferença entre ameríndios e modernos, ignorando os vínculos históricos entre ambos.

\section{Diversidade Situada: Indígenas Mulheres em contexto amazônico}

A perspectiva teórica da pesquisa é tributária da crítica que questiona o caráter universal, homogêneo e transcultural da categoria "mulher". Piscitelli (2002) explicita que a conceituação homogeneizante e etnocêntrica da categoria "mulher" tem, inicialmente, a missão de articular politicamente o sujeito do feminismo para agir em busca da libertação da opressão "patriarcal". Porém, a mulher que se apresenta como sujeito hegemônico do feminismo nada tem de abstrata: é branca, de classe média, ocidental, urbana e heterossexual, sendo silenciadas vivências e subjetividades outras. O paradigma contribui para a invisibilização, folclorização e exotificação de corpos, trajetórias e culturas. A desterritorialização da categoria "mulher" implica no diálogo com os saberes locais e com os usos autorreflexivos das culturas, evitando concepções essencializantes.

Tais críticas são delineadas a partir das distintas experiências de mulheres latino-americanas, negras, lésbicas, trabalhadoras rurais e indígenas, que denunciam que o feminismo que se fortaleceu a partir da segunda onda teve como uma de suas consequências a universalização de leituras da experiência de opressão e de emancipação de mulheres, que desconsideraram e desqualificaram a pluralidade e a diversidade de suas vivências. Quando a identidade de gênero passa a ser atravessada pelo racismo, pelo etnocentrismo, pela heteronormatividade, a própria 
universalidade da categoria mulher passa a ser questionada. A categoria passa a operar sob rasura.

As intervenções políticas e analíticas advindas de lugares de enunciação dissidentes não só provocaram profundas desterritorializações em relação ao sujeito do feminismo hegemônico como também fizeram emergir outras possibilidades analíticas para os estudos de gênero, que considerem as tensões e antagonismos das posições (múltiplas) dos sujeitos em relações de poder e os marcadores sociais da diferença que distinguem de forma indelével essas posições. As críticas e denúncias ao feminismo hegemônico e aos estudos de gênero são explicitadas por Haraway (2004):

[0] poder universalizante do sistema sexo-gênero e a ruptura analítica entre o público e o privado foram também agudamente criticados politicamente, particularmente pelas mulheres de cor, como parte das tendências etnocêntricas e imperialistas dos feminismos europeus e euro-americanos. A categoria gênero obscurecia ou subordinava todos os outros "outros". Os esforços para utilizar conceitos ocidentais, ou "brancos", de gênero, para caracterizar a "mulher do Terceiro Mundo" freqüentemente resultaram na reprodução do discurso orientalista, racista e colonialista (HARAWAY, 2004, p. 237, sic.)

E no que tange às indígenas mulheres, interessa-nos romper com os estereótipos analisados por Lea (1999) e Lasmar (1999) em dois artigos diferentes. A primeira autora demonstra que grande parte da literatura etnológica mais antiga relega indígenas mulheres ao espaço da periferia e da natureza, tomando-as como pouco participativas na dinâmica social das comunidades, e retrata os homens como fazedores de cultura privilegiados, que monopolizariam a vida cerimonial e política das aldeias. Lasmar (1999) problematiza o estereótipo da índia sexualmente promíscua e iniciadora sexual, presente na narrativa misógina cristã e propagado na literatura das Ciências Sociais em função, segundo a autora, da predominância de um ponto de vista masculino e de interpretações androcêntricas sobre o universo indígena.

Em contrapartida, o trabalho que se realiza se insere em um contexto de destaque do protagonismo de indígenas mulheres, que, principalmente por meio de organizações políticas, tem reivindicado (em 
um diálogo nem sempre fácil) a importância da transversalidade de gênero e de etnia nas ações e políticas públicas do Estado. As indígenas mulheres passam a defrontar-se com os antagonismos de lutar por uma agenda política coletiva e pelas demandas específicas que concernem aos seus lugares de fala. Desse modo, retratar trajetórias e narrativas das interlocutoras também implica o diálogo com o referido contexto.

No contexto amazônico, as situações de violência contra indígenas mulheres podem ser comparadas aos contextos de guerra, em que os corpos são violados de forma contínua (BELTRÃO, 2013). O genocídio de indígenas mulheres se dá por meio de violências domésticas, abortos não seguros, expulsão compulsória e tráfico de pessoas, situações que produzem danos físicos e morais incalculáveis às pessoas que as sofrem. O relativo afastamento dos centros urbanos facilita o silenciamento e ocultação da violência sofrida e reduz consideravelmente as possibilidades de denúncia, acolhimento, atendimento e reparação (BELTRÃO, 2013). Somando-se essas questões à desconsideração, por parte do Estado, dos povos indígenas como sujeitos de direito e detentores de noções de justiça, pessoa e território que são específicas, pode-se afirmar que, no contexto amazônico, os corpos de indígenas mulheres são silenciosa e impunemente violentados.

Atentar para as narrativas das mulheres tembé-tenetehara, a partir do que foi explicitado, é um esforço que vai além de retomar o protagonismo de vozes subalternizadas. Trata-se de uma tentativa de constituição de possibilidades de outra epistemologia, outras referências e sensibilidades, diferentes das que o pensamento colonial afirma serem as únicas dignas de serem aprendidas e respeitadas. A partir das falas desses sujeitos, confronta-se a tentativa histórica de epistemícidio (SANTOS, 2010) e assimilação que incide sobre os povos indígenas, e mais especificamente sobre indígenas mulheres. Trata-se de uma opção metodológica que abriga intenções e responsabilidades políticas, de contemplar enunciações ditas e tomadas como periféricas e arbitrariamente alijadas pelo pensamento ocidental e colonial. A análise conflui para as formulações de Sahlins (1997), que afirma:

[o] que se segue, portanto, não deve ser tomado como um otimismo sentimental, que ignoraria agonia de 
povos inteiros, causada pela doença, violência, escravidão, expulsão do território tradicional e outras misérias que a "civilização" ocidental disseminou pelo planeta. Trata-se aqui, ao contrário, de uma reflexão sobre a complexidade desses sofrimentos, sobretudo no caso daquelas sociedades que souberam extrair, de uma sorte madrasta, suas presentes condições de existência (SAHLINS, 1997, p. 53).

Compreende-se, portanto, ser a corporeidade uma chave relevante para a discussão dos significados sobre gênero, estratégias de empoderamento e exercício do protagonismo das indígenas mulheres. Focaliza-se os devires experienciais do corpo - vivenciados de forma conflituosa e plural - como produtores de sentidos, atos e distinções identitárias, abrigando processos de integração e diferenciação.

\section{Resultados a partir da revisão das publicações}

\section{Estudos Feministas}

A Estudos Feministas é um periódico qualificado pela CAPES como sendo de nível $\mathrm{A} 1$ que discute questões de gênero e sexualidade a partir de uma perspectiva multidisciplinar. Apresenta tiragem quadrimestral e possui circulação nacional e internacional. A publicação recebe artigos, ensaios e resenhas em português e espanhol, e todo o material publicado pode ser acessado gratuitamente em formato PDF no site da revista ou na plataforma Scielo.

No tocante ao aspecto quantitativo, foram encontrados, durante os seis anos que contemplamos no levantamento, 82 artigos que abordam a temática do corpo. O esquema abaixo apresenta a distribuição desses trabalhos por ano: 
Figura 1 - Número de artigos sobre gênero e corpo - Revista Estudos Feministas.

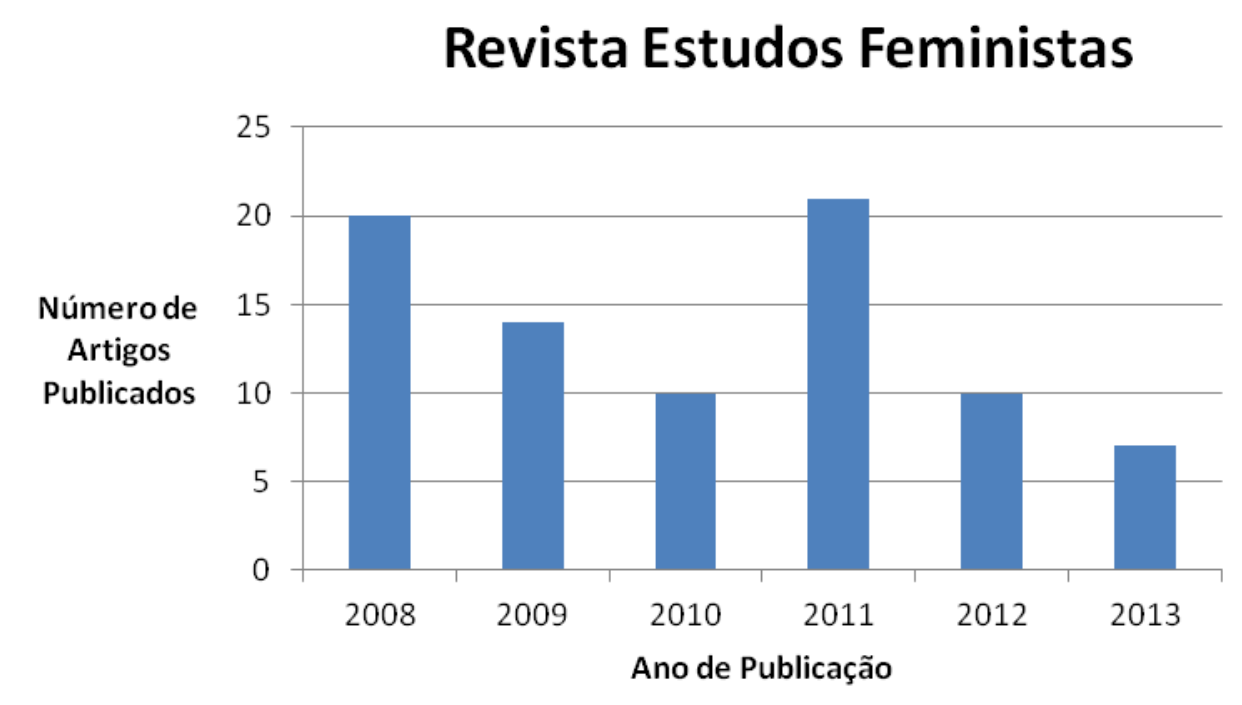

Fonte: Revista Estudos Feministas (2008-13). Autora: Camille Barata.

Dentre os artigos pesquisados nos três primeiros anos, observase certo padrão nas temáticas abordadas: discute-se predominantemente a representação midiática do corpo em videogames, revistas, telenovelas e na literatura (MENDES, 2008; MATOS e LOPES, 2008; BRIGADEIRO e MAKSUD, 2009); o corpo sob a perspectiva da saúde, especialmente no que tange à questão do aborto e de mulheres em situação de violência (COLARES e CHIES, 2010; RIUS, 2008; SCAVONE, 2008b); e os avanços e possibilidades de uma epistemologia feminista, que inclui a (re)formulação da noção de corpo, sobretudo dos corpos de mulheres (SCAVONE, 2008a; GUIJARRO, 2009; FONSECA, 2010). O principal aporte teórico utilizado em tais estudos foram as considerações de Butler (2003), especialmente no que tange à desnaturalização das categorias sexo/gênero.

Nos três anos seguintes, as questões anteriormente citadas dão lugar aos estudos queer e "pós-feministas". Passam a serem focalizados os corpos dissidentes e transgressores, perturbadores da normatividade heterossexual e binária. Os estudos na revista lançam seus olhares à questão travesti, transexual e à manipulação do corpo a serviço das identidades de gênero (BALSA, 2011; POCAHY, 2012, SALES e PARAÍSO, 2011). Em tais estudos, além da contribuição de Butler (2003), as 
formulações de outras teóricas queer como Preciado (2002) e Louro (2007) também foram adotadas.

No ano de 1999, a Estudos Feministas publicou um número com uma sessão com quatro artigos que discutiam as relações de gênero entre povos indígenas (LASMAR, 1999; MCCALLUM, 1999; LEA, 1999; RODRIGUES, 1999). Porém, durante o período de seis anos que foi contemplado no levantamento, o tema só foi retomado no ano de 2013 , a partir de artigos que discutiam a questão pós-colonial.

Destacamos, nesse sentido, a contribuição de Santos e Schor (2013), que, em entrevista com Ella Shohat e Robert Stam, levantam a problemática do pós-colonialismo na visão dos intelectuais indígenas: os povos indígenas não se consideram incluídos na retórica póscolonial, uma vez que esta prioriza a diluição de fronteiras e o cosmopolitismo. Os povos indígenas, em contrapartida, retomam a noção de territorialidade, sendo o território um espaço de vida, tradições e afetividade.

\section{Cadernos Pagu}

A Cadernos Pagu é um periódico qualificado pela CAPES como sendo de nível $\mathrm{A} 1$ que discute questões de gênero e sexualidade a partir de uma perspectiva multidisciplinar. O periódico pretende fomentar discussões de gênero para o âmbito acadêmico e para organizações não governamentais e governamentais. Todo o material publicado pode ser acessado gratuitamente em formato PDF no site da revista ou na plataforma Scielo.

No tocante ao aspecto quantitativo, foram encontrados, durante os seis anos que contemplamos no levantamento, 44 artigos que abordam a temática do corpo. O esquema abaixo apresenta a distribuição desses trabalhos por ano: 
Figura 2 - Número de artigos sobre gênero e corpo - Cadernos Pagu.

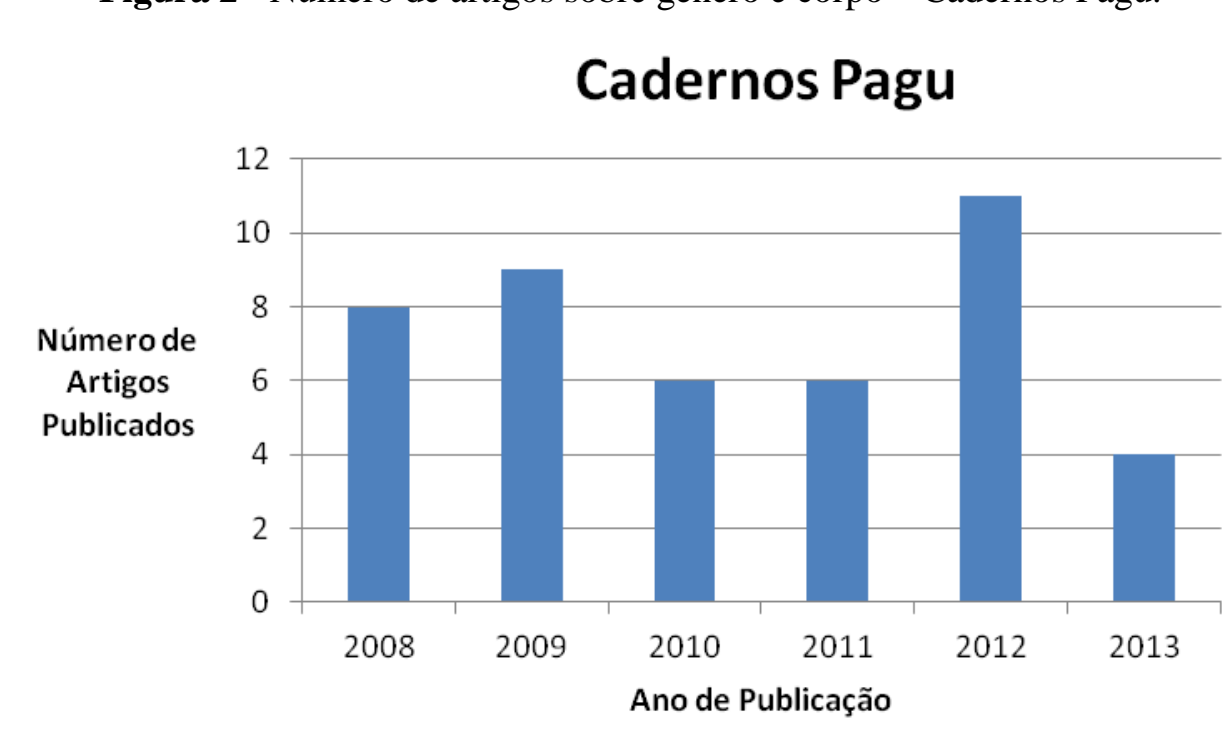

Fonte: Cardenos Pagu (2008-13). Autora: Camille Barata.

Os principais eixos temáticos observados nos três primeiros anos foram: corpos de pessoas que se prostituem (TEIXEIRA, 2008; OLIVAR, 2008; JIMENEZ e ADORNO, 2009) e corporalidades expressas por meio de mídias digitais (SILVA, 2010; PARREIRAS, 2010). Nesses trabalhos, os aportes teóricos mais acionados foram Douglas (1991) e Bataille (2004).

Nos três anos seguintes, os campos temáticos de problematização do corpo que foram identificados são: os corpos representados na pornografia (WILLIAMS, 2012; LEITE, JR., 2012) e corpos e vozes dos feminismos dissidentes, que não se conformam ao perfil normativo de mulheres brancas, ocidentais, europeias e heterossexuais (MINELLA, 2013; FORTES, 2013). Os principais aportes teóricos utilizados foram Reicher e Koo (2004) e Foucault (1977).

Foram encontrados dois artigos e uma resenha7 que discutiam o corpo e o gênero em relação aos povos indígenas ${ }^{8}$, dentre os quais, o trabalho de Minella (2013) é significativo na medida em que analisa a ausência da abordagem sobre as interseções entre gênero, raça e etnia no Brasil. A autora considera que essa lacuna está relacionada a uma

\footnotetext{
${ }^{7}$ Cf. Minella (2013), Hamlin eVandenberghe (2013) e Ferreira (2009).

${ }^{8}$ O levantamento e a análise dos dados de todas as revistas foram finalizados em novembro de 2013. Posteriormente, a Cadernos Pagu publicou um número referente ao segundo semestre de 2013, que continha três trabalhos que debatiam questões de gênero e sexualidade entre povos indígenas. Cf. McCallaum (2013), Rubio (2013) e Rosa (2013).
} 
dimensão política que envolve "[...] clivagens de gênero, classe e etnia, embora essas nem sempre sejam enfatizadas"(MINELLA, 2013, p. 99).

\section{Horizontes Antropológicos}

Horizontes Antropológicos é um periódico semestral, qualificado pela CAPES como sendo de nível A1, publicado pelo Programa de PósGraduação em Antropologia Social da Universidade Federal do Rio Grande do Sul (UFRGS). O periódico está aberto a temas que possam interessar a antropologia, com artigos que podem ser publicados em português, espanhol, francês e inglês. Todo o material publicado pode ser acessado gratuitamente em formato PDF no site da revista ou na plataforma Scielo.

No tocante ao aspecto quantitativo, foram encontrados, durante os seis anos que contemplamos no levantamento, 17 artigos que abordam a temática do corpo. O esquema abaixo apresenta a distribuição desses trabalhos por ano:

Figura 3 - Número de artigos sobre gênero e corpo - Horizontes Antropológicos.

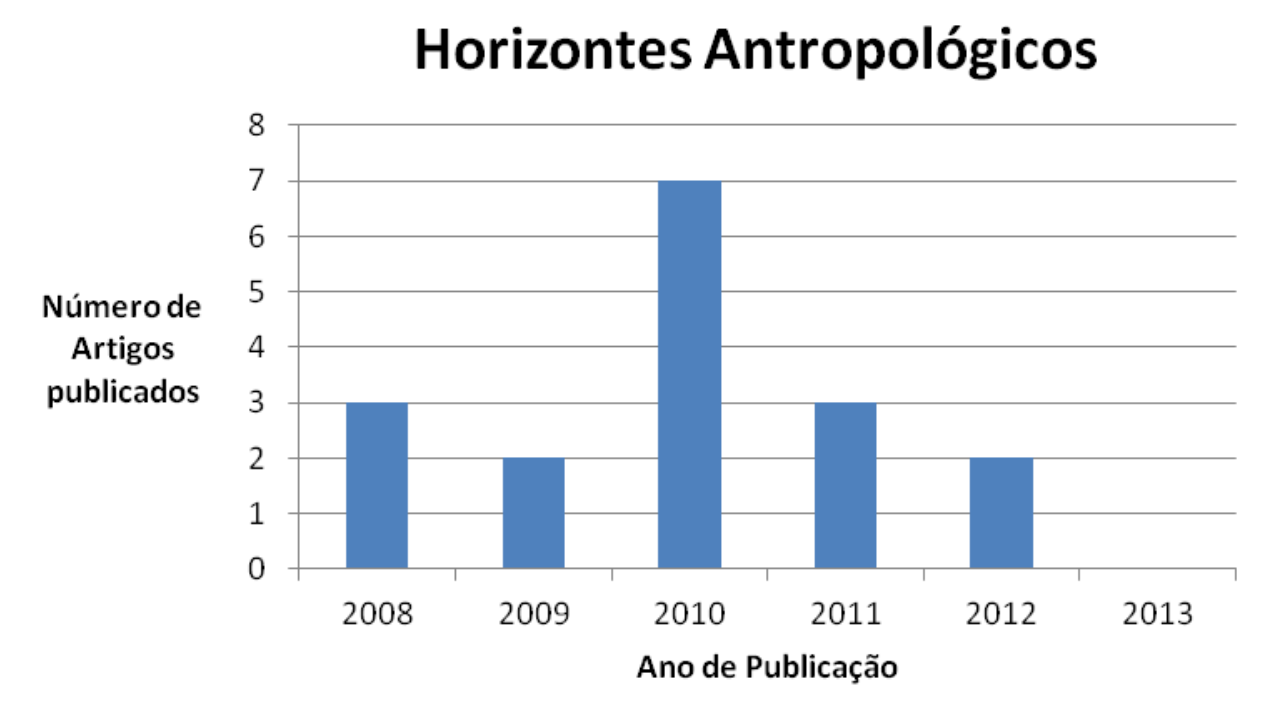

Fonte: Horizontes Antropológicos (2008-13). Autora: Camille Barata.

Nos três primeiros anos, observou-se um padrão temático presente sobretudo nas publicações do ano de 2010: a noção de corpo associada aos ciclos de vida e construção da pessoa (COHN, 2010; 
GUIMARÃES, 2010). Os principais aportes teóricos utilizados foram: Seeger, DaMatta e Viveiros de Castro (1979) e Coelho de Souza (2004).

Nos três anos que seguiram, o eixo temático detectado relaciona o corpo com a dimensão "biológica" dos hormônios (ROHDEN, 2011; MANICA, 2011). Os principais aportes teóricos utilizados foram Martin (2006) e Oudshoorn (1994).

Foram localizados quatro artigos que trabalhavam a questão do corpo e do gênero entre os povos indígenas, dentre os quais destacamos os trabalhos de Cohn (2010) e Guimarães (2010). O primeiro trata da fabricação do corpo entre os Mebengokré-xikrin e como essa fabricação, sobretudo entre as crianças, é determinante para a demarcação de gênero entre esse povo. $O$ segundo discute como o corpo influencia na cosmologia sobre os ciclos de vida e na formação da pessoa entre os Sanumá-Yanomami.

\section{Dialógos com mulheres tembé-tenetehara: corpo em cena}

No final de fevereiro de 2014, ocasião em que ocorria o /I Seminário de Etnodesenvolvimento no município de Altamira, uma das discussões de mesas redondas que integravam a programação do evento pontuou a questão da conversão de indígenas universitários a religiões evangélicas. Nesse momento, uma das participantes, Dona Maria Xipaya - mais velha e não matriculada nos cursos da UFPA - pediu a palavra e posicionou-se publicamente:

eu não acho que ser evangélica tira a cultura. Porque que sou evangélica e dizem que não sabem nem o que eu sou. [Dizem] "Xipaya, eu não sei o que tu és, [se és] católica, evangélica, eu não sei". Mas eu ando pintada é com coisa de índio. Não uso maquiagem, pintura azul que usam na cara, aqui no olho [aponta para os olhos], né? Nos braço, nas perna, a pintura que eu uso é a pintura de índio mesmo, eu sou índia. Então eu não acho que tira a cultura (Grifo nosso).

Após terminar sua fala, a indígena cantou uma música na língua de seu povo enquanto dançava e desejou às pessoas presentes um bom seminário. Eram os "votos da velha xipaya para cada um de vocês [nós]". 
Sem nos atermos às complexidades engendradas pela adoção de religiões cristãs pelos povos indígenas, algumas questões suscitadas pelo depoimento de Dona Maria Xipaya merecem análise mais detida para os fins dessa pesquisa.

Primeiramente, a intervenção da interlocutora ocorreu num espaço público e universitário, na presença de outros protagonistas de pertenças diversas que eram discentes do Curso de Etnodesenvolvimento e de pesquisadores não indígenas convidados para os debates. A evocação de Dona Maria demonstra uma transformação em relação aos estudos em etnologia que afirmam que as indígenas mulheres - principalmente velhas - movimentam-se e articulam-se, sobretudo, nos espaços privados (SEGATO, 2012; MATOS, 2012).

Em segundo lugar, a interlocutora aciona um saber sobre o corpo (a pintura corporal) para afirmar sua identidade social enquanto indígena. $\mathrm{Na}$ fronteira da alteridade com outros povos tradicionais e com não indígenas, o corpo vem à cena para a afirmação da pertença étnica. Em seguida, a performance estilizada envolvendo canto e dança sela as articulações entre etnicidade e corporeidade. O comentário de Dona Maria também abriga uma crítica cujo teor é eminentemente geracional: direcionava-se às indígenas mais jovens presentes no seminário e que usavam maquiagem.

Este não é um trabalho sobre as mulheres xipaya: o trabalho trata das corporeidades entre as mulheres tembé-tenetehara. Porém, as clivagens percebidas a partir da situação ocorrida em Altamira aproximam-se e introduzem dimensões reveladoras das situações vivenciadas em campo.

Da família linguística Tupi-Guarani, do Tronco Tupi, os Tembé ou, como também se autonomeiam, os Tenetehara moradores de Santa Maria do Pará são pouco conhecidos na literatura etnológica nacional. A história do povo Tembé, assim como da maioria dos povos indígenas do Brasil é marcada por transformações produzidas pelo contato com a sociedade envolvente. Gomes (2002), ao falar sobre os TembéTenetehara afirma que seus membros saíram dos territórios nas proximidades do rio Pindaré, no Maranhão, migrando para o rio Gurupi, divisa entre os estados do Pará e Maranhão, posteriormente indo para o 
alto dos rios Capim e Guamá, no estado do Pará, até as proximidades dos rios Maracanã, Prata e Jeju no nordeste do Pará.

Wagley e Galvão (1955) previram, em seus estudos, o desaparecimento dos Tenetehara em função de uma suposta "fragilidade" e "homogeneidade" do discurso cosmológico e da vida religiosa dessas sociedades. Segundo os autores, em função do contato com a cultura europeia, "[o] processo de transformação dos Tenetehara em caboclos estará em vias de se completar no espaço de uma geração ou um pouco mais" (WAGLEY e GALVÃO, 1955, p. 185).

Embora a história, e as trajetórias de vida dos Tembé em Santa Maria demonstrem que a "profecia antropológica" não se realizou, as falas dos dois antropólogos revelam o que os estudos descoloniais denominam como uma das "faces ocultas da modernidade": a colonialidade. A "mão pesada" da colonialidade incide sobre os povos indígenas, se não levando à exterminação física, conduzindo ao apagamento e à repressão de suas línguas nativas, cosmologias e modos de vida.

No caso dos Tembé em Santa Maria, este processo assume contornos específicos, pois se relaciona com a cristianização forçada desse povo a partir da ação missionária no território indígena, cujas principais fontes históricas reportam ao ano de 1913. Parte do projeto dito "civilizador" empreendido por esses agentes é elucidado pelo contexto estabelecido na Colônia Santo Antônio do Prata, educandário que recebia as crianças indígenas sequestradas de suas comunidades e apartadas de seus parentes para serem educadas, catequizadas e "civilizadas" com base na pedagogia cristã dos missionários Capuchinhos.

Beltrão (2012) explica que o projeto introduziu 25 famílias de colonos entre as 55 famílias indígenas, estendendo o raio de ação para além dos limites do Prata, alcançando as vilas de Jambuaçu e Castanhal. A estratégia era retirar indígenas crianças e jovens das famílias de origem, impedindo-as de ser educadas entre os pais. A autora também descreve as formas de resistência realizadas pelos indígenas na época, dentre as quais a embriaguez se destaca como o momento em que os pais iam ao encontro dos filhos tomados, reivindicando sua volta. Os (des)caminhos da trajetória do povo Tembé-Tenetehara se relacionam, 
portanto, com histórias de violações de direitos, ou o que Beltrão (2012) caracteriza como etnocídio "cordial". Trata-se de uma trajetória que diz das resistências e agenciamentos dos Tembé em relação a um longo período em que dizer-se indígena era assinar sentença de morte.

Os depoimentos e percepções apresentadas a seguir são resultado de nossas estadas entre os Tembé, seja hospedadas nas casas de famílias na comunidade, seja em pousadas alugadas nas proximidades, uma vez que a cidade cresceu em torno da aldeia, o que coloca os Tembé em contato (e conflito) constante com não indígenas. Todos os nomes das interlocutoras citadas foram alterados, uma vez que as histórias relatadas o foram em relação de confiança e confidencialidade, além de serem narrativas que mobilizam sofrimento, memórias de violências domésticas, violências médicas e tentativas de abuso sexual. Preservar as identidades das interlocutoras é, portanto, um imperativo ético do trabalho.

A aproximação com as interlocutoras se deu a partir da circulação em meio a atividades cotidianas que as mesmas realizavam. Ajudar a lavar a louça, limpar e mesa, fazer café e varrer a casa possibilitaram os diálogos mais frutíferos e a escuta dos depoimentos mais desenvoltos. Posteriormente, pôde-se perceber que o espaço da casa é um cenário visceral de decisão política na comunidade, onde o protagonismo dessas interlocutoras se exerce de forma contundente. As decisões "oficiais", proferidas em público pelos homens nas assembleias indígenas, só são tomadas a partir da consulta prévia às mulheres, dentro das casas.

Essa dinâmica aponta, inclusive, para a existência de lideranças silenciosas, que são, sobretudo, as mulheres mais velhas, que dentro das casas, em parceria com seus filhos e maridos, articulam e mobilizam decisões importantes para a aldeia, sem precisar ir às assembleias e reuniões. Essa percepção ilustra bem o fato de que não é possível pensar a participação política de pessoas indígenas a partir dos modelos ocidentais, pois espaços como a cozinha, a sala e a mesa de jantar são também espaços onde a política feita por mulheres se exerce.

Por outro lado, o intenso contato e translado com a sociedade envolvente, principalmente a partir do diálogo com órgãos governamentais, aumentou a importância do papel de intermediação com o mundo de fora da aldeia e, consequentemente, o prestígio e o 
poder dos homens nas decisões coletivas, devido ao espaço público de negociação pertencer tradicionalmente ao universo masculino. $O$ aumento da valorização do espaço público parece ter gerado uma recente preocupação das mulheres em ocupar esse cenário para que possam ser representadas adequadamente.

As Tembé mais jovens passam, então, a ocupar, principalmente na assembleia, cargos de secretárias e tesoureiras, o que gera novas tensões junto a seus pares masculinos, traduzidas inclusive por falas como "o que vocês têm pra dizer aqui? Vão falar da panela que queimou?". Percebe-se, a partir do exposto, que os modos de participar politicamente são alterados de acordo com a geração a que pertencem as interlocutoras.

No tocante à corporeidade, a primeira questão que se mostrou latente é o confronto reiterado das mulheres com a questão da cor, no diálogo com não indígenas. Durante uma das conversas com Dona Rita, uma das mulheres mais velhas que é membro da comunidade, ela relatou:

durante toda a minha vida as pessoas não acreditaram que eu era indígena, porque eu sempre fui muito branca, né? Lembro quando eu era jovem, e dava aula na escola pública, eu andava sempre arrumada, achava que professora tinha que andar arrumada... Um dia vieram procurar o meu pai e eu tava na porta de casa e a pessoa não acreditou que eu era filha dele. Falou: "Tu não parece índia, bonita, branca e arrumada desse jeito" (Grifo nosso).

A interpelação demonstra o quanto o corpo indígena é racializado na fronteira da alteridade, e o quanto essa racialização articula-se com a distinção de classe. A cor parece ser significante de como o discurso etnocêntrico recria o "ser" e o "parecer" indígena, resultando em tensões e discriminações e desrespeitando a autodeterminação dos povos, dentro de uma lógica homogeneizante. A própria incredulidade quanto ao fato de uma indígena mulher ser "bonita" diz do não reconhecimento dos povos indígenas enquanto sujeitos.

De fato, vários relatos em tom de indignação surgiram reafirmando que a cor da pele ou do cabelo das pessoas tembétenetehara não poderia ser utilizada para deslegitimar suas pertenças 
étnicas. Há "pessoas de pele branca na comunidade", o que não apaga suas experiências e trajetórias enquanto indígenas. Uma das interlocutoras chega mesmo a afirmar: "as pessoas acham que não existe índio louro, mas a minha mãe era loura e ela era índia. Meu pai era diferente, era moreno, cabelo preto, mas minha mãe lourinha, de cabelo liso" (Grifo nosso). Desse modo, percebe-se que o contato com não indígenas mobiliza certo discurso sobre a corporeidade que reitera a coexistência da diversidade no contexto comunitário, demonstrando que "não precisa ser todo mundo igual aqui". Confronta-se, a partir de tais falas, a retórica etnocêntrica que homogeneíza e cria estereotipias sobre o povo Tembé-Tenetehara.

As violações que incidem sobre o corpo feminino revelaram os relatos de maior sofrimento quando se tratou da questão da violência doméstica e sexual. As narrativas sobre esses assuntos foram constantemente pontuadas por choros das protagonistas, denotando o quanto estes foram momentos dolorosos de serem lembrados e abordados. O primeiro relato veio de uma interlocutora também idosa, que aqui chamaremos de Dona Cássia. A respeito da violência praticada no passado pelo marido ela diz:

eu era dominada de não mandar nem em mim mesma.
O meu marido deu muito nó. Tinha que lutar pra
sobreviver, porque o homem era brabo. Gastava todo o
dinheiro da casa em bebida e mulher, a gente mal tinha
o que comer, meus filhos viviam com medo. Ele
desaparecia vários dia e depois a gente só era avisado,
tava preso na delegacia. Foi muito difícil, minha filha
(Grifo nosso).

As mulheres mais velhas afirmam que com o avançar da idade arrefeceu a violência, pois os homens ficavam deprimidos quando "paravam de funcionar", "broxavam". Embora os insultos, as palavras ofensivas e "que machucam a gente" continuassem a ser proferidas, conforme pontua Dona Rita: "meu marido tem a boca muito imunda, muito imoral, não diz uma palavra que Deus goste".

Em uma das idas a campo, soube-se que o marido de Dona Cássia vinha apresentando desmaios frequentes e um cansaço intenso. Ele já era idoso e, segundo seus filhos, sempre foi forte e ativo, o que levou a família a procurar vários médicos. Uma vez que os resultados dos 
exames e consultas não identificaram alterações, os familiares iniciaram uma corrente de orações pela saúde do parente. Dona Cássia disse ter perguntado inúmeras vezes se ele não queria confessar nada, pois acreditava que o estado do marido era fruto do remorso pelos sofrimentos que havia infringido a ela. Uma das filhas, presente durante a conversa, acrescentou: "acho que é castigo, por todas as maldades que ele fez com a gente".

O crescimento da cidade em torno da aldeia e a intensificação do diálogo com não indígenas resultou no aumento de uniões $\mathrm{e}$ casamentos com brancos. A grande maioria dos Tembé-Tenetehara jovens é casada ou namora com pessoas não indígenas. Uma das consequências é o surgimento da alcoolização como problema na aldeia. A bebida alcoólica aparece de forma recorrente como catalisadora das situações de violência enfrentadas pelas mulheres tembé mais jovens. Os maridos não indígenas "chegam bêbados em casa e tiram sangue", segundo as interlocutoras.

Márcia, uma indígena jovem, conta que em um dos dias em que o marido saiu para beber, ela foi refugiar-se na casa dos pais, levando junto os filhos pequenos. No meio da madrugada o marido foi até a casa atrás dela e subiu pelo telhado, adentrando a sala e assustando todos os que ali estavam. Essas situações são geradoras de medo e insegurança e a interlocutora afirma: "eu tenho medo de um dia ele fazer uma desgraça comigo".

Outro fator que gera conflitos com os maridos é o ciúme e a "posse". Segundo Dona Rita, "o problema é que eles [os maridos] se acham donos da gente". Ela afirmou que o marido desconfiava constantemente de sua fidelidade, atribuindo-lhe inúmeros amantes. Num dia, em um "ataque de ciúmes, eu vinha saindo do banho e ele puxou uma faca pra mim, disse que ia me matar". Dona Rita atribui a responsabilidade de conciliar essas tensões às esposas, dizendo: "se o homem for brabo a mulher tem que amenizar, senão um não vai viver".

Os corpos de mulheres tembé carregam, nesse sentido, a marca da violência física, e suas trajetórias dizem das formas de agenciar, buscar alternativas e resistir. As interlocutoras constroem o "ser sujeito" a partir do enfrentamento de tais situações. Uma das formas de agenciar 
situações de violência se dá por meio da educação dos filhos. Segundo Dona Cássia:

a mulher é que educa o filho. Se ela não mandar ele ir lá, tomar a bença do pai, fazer um carinho no pai, ele não vai, não, fica na dele. Foi por causa de um dos meus filhos que meu marido parou de me bater. Um dia, ele era novinho, magro, magro... Ele virou pro pai e falou: "O senhor nunca mais vai bater na mamãe, hoje foi o último dia". O pai perguntou: "E o que tu vai fazer?". E ele disse: "Eu não sei, mas o senhor não encosta mais um dedo nela". Depois disso, nunca mais ele me bateu.

Uma das filhas de Dona Cássia, ao ver o pai com outras mulheres na rua, "fazia um escândalo, batia nela. Uma vez enchi as coisas da mulher de areia, ficou tudo sujo. Depois ele metia a porrada em mim quando chegava em casa, mas eu nunca deixava barato". Atualmente as crianças que na infância enfrentaram os pais em defesa de suas mães criam redes de apoio e acolhimento das indígenas mulheres em situação de violência, seja recebendo-as em suas casas, rezando por elas ou conversando - e constrangendo - os maridos.

Nas imediações da aldeia não existem escolas que ofertam o Ensino Médio. As mulheres que desejam dar continuidade à educação fundamental precisam deslocar-se para as cidades próximas, ficando hospedadas nas casas de parentes e conhecidos, o que gera outras vulnerabilidades. Dona Rita sofreu uma tentativa de estupro por parte do marido de sua madrinha, que a recebeu em casa para que pudesse cursar o Ensino Médio. Ela conseguiu escapar fugindo pela janela da casa.

Márcia também enfrentou o assédio sexual de um professor do Ensino Médio: "ele tentou passar a mão em mim, achando que eu era caboquinha, que não sabia me defender". Todos esses relatos demonstram que o contato com homens não indígenas trouxe as marcas da violência de gênero, inscrita nos corpos das interlocutoras. Porém, frequentar a escola é, para as mulheres tembé, uma forma de sair de situações de precariedade, superar a tutela e estabelecer melhores condições de vida. Amplificando a intenção, trata-se de uma 
forma de cuidar do corpo, de cuidar de si, apesar das tensões ensejadas.

Percebeu-se também que o corpo vem à cena relacionando à saúde e aos cuidados de si. As mulheres tembé detêm múltiplos saberes relacionados à saúde que são repassados geração após geração e negociados com as práticas da medicina ocidental. São formas de cuidar do corpo doente, proteger-se contra maus espíritos, além de conceber e significar pessoa e corpo.

Uma das interlocutoras, reconhecida como a "capitoa" da aldeia "por ser uma das mais antigas dos nossos antepassados", relata que nos tempos antigos, quando houve grande incidência de hanseníase na região, ela conseguiu paralisar o avançar da doença no corpo de um membro da aldeia utilizando as propriedades do mucuracaá, uma planta medicinal que também é utilizada entre os Tembé para combater o "mau-olhado". Outras indígenas afirmam que uma mulher grávida que estivesse sob os cuidados da capitoa estaria em boas mãos, uma vez que ela acompanhava a gestação desde os primeiros meses até a hora do parto, no qual a mulher era virada de lado e dava a luz enquanto a interlocutora rezava em sua barriga.

Durante uma das idas a campo, a mãe de uma menina que havia nascido há pouco tempo encontrava-se aflita, pois a bebê não parava de chorar e não costumava ser assim. Nesse momento, Dona Maria, sogra da mãe da criança, entrava na casa e, ao saber da situação, perguntou se a menina havia ido tomar banho de igarapé. Ao receber resposta afirmativa, a interlocutora disse:

minha filha pegue alho, amasse e misture com álcool e deixe um tempo. Depois passe com o dedo na palma da mão da neném, na sola do pé, no braço e na coxa, em forma de cruz. Vai ficar um cheirinho ruim, mas não tem problema, ela vai melhorar. Ela deve ter visto alguma coisa no igarapé, criança é muito sensível, parece um pintinho novo. Quando eu era pequena, minha tia levava a gente pro igarapé, mas ela entrava primeiro, pedia licença pra mãe da água pra gente entrar e jogava o alho na água, aí o banho era sossegado. 
A paçoca de gergelim preto "pisada" com hortelã é utilizada para "botar pra fora" (as indígenas não utilizam o termo "aborto"), principalmente quando a gravidez ameaça a vida da mãe ou quando o parto é de risco. Para mulheres grávidas que sentem dores, o chá de gengibre é ministrado. Para inflamações, especialmente em casos de problemas de próstata, o caroço de abacate mostra-se eficaz. Pessoas especializadas rezam na cabeça de crianças com febre. Bebês, quando morrem antes do batismo, choram durante sete dias e precisam ser batizados para que "descansem". A última prática mostra-se elucidativa da forma tembé de pensar a construção da "pessoa", a partir do ato de batizar a criança morta. Para os Tembé-Tenetehara, não se deve negar às pessoas mortas, quando oriundas de famílias cristãs, o direito ao ritual de batismo que as forma e legitima.

Por outro lado, o contato com o sistema ocidental de ação para saúde trouxe à tona histórias de arbitrariedades e violências. A respeito, Dona Maria relata que teve seus filhos em um curto intervalo de tempo, pois jamais pôde fazer o controle das gravidezes por meio do uso de métodos contraceptivos. Quando a interlocutora estava amamentando, a menstruação se desregulava, impedindo-a de calcular tabelinhas. Diante disso, ela foi ao médico, solicitando que o mesmo receitasse remédio anticoncepcional, e recebeu uma resposta negativa, pois o medicamento "prejudicava na amamentação". Quando chegou a nona gravidez, a interlocutora enfrentou complicações no parto e a criança faleceu. Após a retirada do bebê, o médico também cortou as trompas da interlocutora, à sua revelia, afirmando que "já tava bom de filho". Os dois casos são elucidativos do cerceamento da autonomia da protagonista com relação ao próprio corpo e ao controle do número de filhos que desejava ter.

Por fim, a última questão percebida é que o corpo das indígenas mulheres abriga sentidos políticos. Elucidativo desse fato é que a pintura corporal - feita com jenipapo para o corpo e urucum para o rosto -, marca distintiva do "ser indígena", é realizada em momentos específicos, considerados importantes por homens e mulheres tembé, como o primeiro dia de aula de crianças e jovens e nos momentos de assembleia. Inclusive, várias crianças indígenas foram impedidas de entrar em sala de aula por estarem com o corpo pintado, o que mostra 
que a escola não está apta para acolher a diversidade e segue orientada por modelos etnocêntricos. A preparação para a assembleia inclui o uso de adereços de arte plumária adquiridos de artesãos kayapó pelos líderes masculinos, evidenciandoo contato e as trocas mantidas com outras etnias.

As situações acima descritas, integrantes das observações de campo, revelam que, mesmo enfrentando situações de precariedade e violência, as mulheres exercem seu protagonismo instituindo o "ser sujeito" e encontram alternativas para agenciar situações de poder assimétricas. O corpo e as múltiplas corporeidades que coexistem entre as interlocutoras são territórios privilegiados da resistência das indígenas mulheres e das formas de cuidar de si mesmas. Conforme pontuou Dona Maria, ao contar a história do seu povo:

o nosso povo foi muito massacrado no Prata. Morreu muita gente. A gente jamais podia dizer que era índio, até hoje nós vivemos discriminados. Hoje tá muito melhor, a gente vive junto, faz nossas festas, cuida uns dos outros e o nosso povo se alegra. Mas vive com a discriminação. Não podemos usar uma roupa, que já dizem que nós não somos índios. Eu vou dizer que eu sou uma portuguesa, sendo que eu não sou? Até tem gente que diz, mas eu não digo. Eu digo o que eu sou, eu sou Tembé. Mas tem que viver com a discriminação.

\section{O desafio permanece...}

A literatura que problematiza o corpo como tema é vasta nas Ciências Humanas. O levantamento bibliográfico e a revisão crítica, muito embora seja apenas um esboço que se pretende representativo, permitiu entrever a multiplicidade de perspectivas sob as quais o corpo pode ser discutido no contexto dos estudos de gênero.

Por outro lado, a revisão desta literatura trouxe à tona a escassez de discussões dentro dos periódicos institucionalmente reconhecidos, sobre como a corporeidade é significante para as relações de gênero estabelecidas entre os povos indígenas. Ainda que já exista uma literatura elucidativa que discute intersecções entre gênero e etnia ${ }^{9}$

\footnotetext{
${ }^{9}$ Conferir: Verdum (2008), Lasmar (2005), Luciano (2006), Sacchi e Gramkow (2012). Apenas para citar os mais conhecidos.
} 
organizada em livros, teses e coletâneas. São textos que versam sobre questões como a violência, a inserção de indígenas em contextos urbanos, representações históricas sobre indígenas mulheres e a relação entre Estado Nacional e povos indígenas por meio das leis e normas jurídicas. Temáticas plurais, que tem em comum a preocupação em refletir sobre o modo como o gênero se espraia nas vivências e trajetórias dos povos indígenas.

A lacuna nos periódicos aponta para o fato de que, apesar de os estudos de gênero terem avançado no sentido de romper com os perfis socioculturais do "centro" e atualmente começarem a contemplar subjetividades outras, esses estudos ainda seguem profundamente orientados pela matriz urbana e ocidental.

Propomo-nos a pensar esta lacuna a partir da percepção de Bourdieu (1983), que concebe o campo científico como espaço de lutas e antagonismos que induz e reproduz desigualdades. O autor afirma:

$$
\begin{aligned}
& \text { [...] o campo científico é sempre o lugar de uma luta, } \\
& \text { mais ou menos desigual, entre agentes desigualmente } \\
& \text { dotados de capital específico e, portanto, } \\
& \text { desigualmente capazes de se apropriarem do produto } \\
& \text { do trabalho científico que o conjunto dos concorrentes } \\
& \text { produz pela sua colaboração objetiva ao colocarem em } \\
& \text { ação o conjunto dos meios de produção científica } \\
& \text { disponíveis (BOURDIEU, 1983, p. 136). }
\end{aligned}
$$

Ainda que a emergência das vozes de intelectuais negros e indígenas desestabilize a reprodução da ausência de discussões sobre a relação entre gênero, raça e etnia, a grande maioria dos estudiosos que discutem questões de gênero é branca e oriunda de famílias de imigrantes europeus (MINELLA, 2013). São, portanto, historicamente detentores de um capital cultural rentável para o meio acadêmico, o que permite a propagação dessa representação parcial no que tange às relações de gênero.

Concorda-se com Esteban (2004), para quem uma Antropologia e pode-se aqui estender a colocação para as Ciências Humanas no geral - do corpo responsável e comprometida deve contribuir para a transformação social e para o empoderamento de sujeitos em situação de subalternização ou discriminação, como é o caso de indígenas mulheres. 
A revisão teórica realizada, dialogando com as narrativas das mulheres tembé, trouxe a percepção de que o corpo está em cena. No caso dessas protagonistas, o corpo vem à cena tanto como alvo de violências e estigmas quanto como território de lutas e afirmações identitárias. Essa relação se adensa na medida em que é no corpo que se inscreve a violência da sociedade envolvente, que desrespeita a autodeterminação dos povos e os lugares de enunciação de indígenas mulheres. Nesse sentido, as práticas corporais das Tembé-Tenetehara também perpassam um empreendimento anti-hierárquico e desestabilizador da normatividade etnocêntrica e anunciam e enunciam a identidade étnica e as mulheridades plurais das interlocutoras.

O corpo feminino tembé que se autoafirma provoca, perturba e desterritorializa as corporeidades dominantes desde o campo estético até o campo político propriamente dito. É um corpo capaz de subverter o corpo padrão dominante. Pode-se dizer que, mesmo em condições aversivas - e por isso mesmo -, a corporeidade das mulheres tembétenetehara ameaça as legitimações e imposições do humanismo etnocêntrico ${ }^{10}$, na medida em que agencia e se insubordina contra suas opressões. Considera-se uma responsabilidade metodológica importante dialogar com esses saberes e fazeres para evitar a reprodução da violência epistêmica colonial em nossas análises.

Os resultados desse trabalho apontam para um desafio teórico e político para os autores que produzem estudos sobre gênero e sexualidade: o de fomentar esse debate acolhendo a diversidade e contemplando os contextos etnicamente diferenciados. Um debate capaz de promover uma equidade de gênero que escape da armadilha da homogeneização.

\section{Referências bibliográficas}

\footnotetext{
${ }^{10}$ Pacheco de Oliveira (2011) afirma que o humanismo etnocêntrico é uma reedição, oriunda do período colonial, de práticas autoritárias e conservadoras, que, disfarçadas de valores humanitários, pressupõem a perversão e irracionalidade dos povos indígenas e utiliza essas suposições como álibi para utilizar contra eles a força bruta, escravização e a pedagogia do medo.
} 
BALSA, Izabel. Ética corporal y sexuación: plasticidad y fluidez en el sujeto del postfeminismo. Estudos Feministas, Florianópolis, n. 12, p. 31-33, 2011.

BARTH, Fredrik. Os grupos étnicos e suas fronteiras. In: LASK, Tomke (Org.). O guru, o iniciador e outras variações antropológicas. Rio de Janeiro: Contra Capa Livraria, 2000. p. 25-67.

BATAILLE, Georges. O erotismo. São Paulo: Arx, 2004.

BELTRÃO, Jane. Histórias 'em suspenso': os Tembé ‘de Santa Maria', estratégias de enfrentamento do etnocídio 'cordial'. Revista História Hoje, São Paulo, v. 1, n.2, p. 195-212, 2012.

. Projeto "Indígenas e quilombolas mulheres em situação de violência: diversidade sociocultural, Direitos Humanos e Políticas Públicas na Amazônia". Belém, 2013. (Manuscrito inédito)

BOURDIEU, Pierre. Outline of a theory of practice. Cambridge: CUP, 1977.

O campo científico. In: ORTIZ, Renato (Org.). Pierre Bourdieu: Coleção Grandes Cientistas Sociais. São Paulo: Ática, 1983. p. 122-155.

BRAH, Avtar. Diferença, diversidade, diferenciação. Cadernos Pagu, Campinas, n. 26, p. 329-365, 2006.

BRIGADEIRO, Mauro; MAKSUD, Ivia. Aparição do Viagra na cena pública brasileira: discursos sobre corpo, gênero e sexualidade na mídia. Estudos Feministas, Florianópolis, n. 17, p. 71-88, 2009.

BUTLER, Judith. Corpos que pesam: sobre os limites discursivos do sexo. In: LOURO, Guacira Lopes (Org.). O corpo educado. Belo Horizonte: Autêntica Editora, 2001. p. 151-172.

. Problemas de gênero: feminismo e subversão da identidade. Rio de Janeiro: Civilização Brasileira, 2003.

COELHO DE SOUZA, Marcela. Parentes de sangue: incesto, substância e relação no pensamento timbira. Mana, Rio de Janeiro, v. 10, n. 1, p. 25-60, 2004.

COHN, Clarice. A criança indígena: a concepção Xikrin de infância e aprendizado. 2000. 185 f. Dissertação (Mestrado em Antropologia Social) - Universidade de São Paulo, [2000].

A criança, a morte e os mortos: o caso mebengokré-xikrin. Horizontes Antropológicos, Porto Alegre, n. 34, p. 93-115, 2010. 
COLARES, Leni; CHIES, Luiz Antônio. Mulheres nas so(m)bras: invisibilidade, reciclagem e dominação viril em presídios masculinamente mistos. Estudos Feministas, Florianópolis, n. 18, p. 407-423, 2010.

COSTA, Claudia J. de Lima. Equivocação, tradução e interseccionalidade performativa: observações sobre ética e prática feministas descoloniais. In: BIDASECA, Karina et al (Org.). Legados, Genealogías e Memorias Postcoloniales: Escrituras Fronteirizas desde el sur. Buenos Aires: Ediciones Godot, 2014. p. 260-293.

CSORDAS, Thomas. Embodiment as a paradigm for Anthropology. Ethos [online], n. 18, p. 5-47, 1990. Disponível em: http://openwetware.org/images/5/54/Csordas.pdf . Acesso em: 05 de julho de 2013.

DAMATTA, Roberto. Um Mundo Dividido: a Estrutura Social dos Índios Apinayé. Petrópolis: Vozes, 1976.

DOUGLAS, Mary. Pureza e perigo: ensaios sobre as noções de poluição e tabu. Lisboa: Edições 70, 1991.

ESTEBAN, Mari. Antropología del cuerpo: Género, itinerarios corporales, identidade y cambio. Barcelona: EdicionsBellaterra, 2004.

FERREIRA, Carolina Branco de Castro. Virando "branca" e subvertendo a ordem? Gênero e transformação no Alto Rio Negro. Cadernos Pagu, Campinas, n. 33, p. 379391, 2009.

FONSECA, Rui Pedro. O activismo estético feminista de Nikki Craft. Estudos Feministas, Florianópolis, n. 18, p. 765-787, 2010.

FORTES, Celeste. O corpo negro como tela de inscrição dinâmica nas relações póscoloniais em Portugal: a Afrocomo (pre)texto. Cadernos Pagu, Campinas, n. 40, p. 229-254, 2013.

FOUCAULT, Michel. História da Sexualidade I: A Vontade de Saber. Rio de Janeiro: Graal, 1977.

GIDDENS, Anthony. The constitution of society. Cambridge: Polity, 1984.

GOMES, Mercio Pereira. O índio na história: o povo Tenetehara em busca da liberdade. Petrópolis: Vozes, 2002.

GROSZ, Elizabeth. Corpos reconfigurados. Cadernos Pagu, Campinas, n. 14, p. 45-86, 2000 .

GUIJARRO, Ester. La sexualidad femenina, El holismo epistemológico y La complejidad: reflexiones para La vida contemporânea. Estudos Feministas, Florianópolis, n. 17, p. 467-480, 2009. 
GUIMARÃES, Silvia. Corpos e ciclos da vida sanumá-yanomami. Horizontes Antropológicos, Porto Alegre, n. 34, p. 261-286, 2010.

HAMLIN, Cynthia; VANDENBERGHE, Frédéric. Vozes do Sul: entrevista com RaewynConnell. Cadernos Pagu, Campinas, n. 40, p. 345-358, 2013.

HARAWAY, Donna. "Gênero" para um dicionário marxista: a política sexual de uma palavra. Cadernos Pagu, Campinas, n. 22, p. 201-246, 2004.

JIMENEZ, Luciene; ADORNO, Rubens. O sexo sem lei, o poder sem rei: sexualidade, gênero e identidade no cotidiano travesti. Cadernos Pagu, Campinas, n. 33, p. 343-367, 2009.

LASMAR, Cristiane. Mulheres indígenas: representações. Estudos Feministas, Florianópolis, v. 7, n. 1 e 2, 1999.

De volta ao Lago de Leite: gênero e transformação no alto Rio Negro. São Paulo: UNESP, 2005.

LEA, Vanessa. Desnaturalizando gênero na sociedade Mebengôkre. Estudos Feministas, Florianópolis, v. 7, n. 1 e 2, 1999.

LEITE JR., Jorge. Labirintos conceituais científicos, nativos e mercadológicos: pornografia com pessoas que transitam entre os gêneros. Cadernos Pagu, Campinas, n. 38, p. 99-128, 2012.

LOURO, Guacira Lopes. O corpo educado: pedagogias da sexualidade. Belo Horizonte: Autêntica, 2007.

LUCIANO, Gersen. O Índio brasileiro: o que você precisa saber sobre os povos indígenas no Brasil hoje. Brasília: MEC/SECAD/LACED/Museu Nacional, 2006. Disponível em: http://www.trilhasdeconhecimentos.etc.br/livros/arquivos/olET12_Vias01WEB.pdf . Acesso em: 20 dez. 2014.

LUGONES, María. Colonialidad y Género. Tabula Rasa, Bogotá, n. 9, p. 73-101, 2008.

MALUF, Sônia. Corpo e corporalidade nas culturas contemporâneas: abordagens antropológicas. Esboços [online], v. 9, n. 9, p. 87-101, 2001. Disponível em: http://www.transes.ufsc.br/arquivos/corpo\%20e\%20corporalidade_Sonia\%20Maluf.pdf . Acesso em: 16 fev. 2013.

MANICA, Daniela. A desnaturalização da menstruação: hormônios contraceptivos e tecnociência. Horizontes Antropológicos, Porto Alegre, n. 35, p. 197-226, 2011.

MARTIN, Emily. A mulher no corpo: uma análise cultural da reprodução. Rio de Janeiro: Garamond, 2006. 
MATOS, Auxiliadora; LOPES, Maria de Fátima. Corpo e gênero, uma análise da revista TRIP Para Mulher. Estudos Feministas, Florianópolis, n. 16, p. 61-66, 2008.

MATOS, Maria Helena. Mulheres no movimento indígena: do espaço da complementaridade ao lugar da especificidade. In: SACCHI, Ângela; GRAMKOW, Márcia (Org.). Gênero e povos indígenas. Rio de Janeiro: Museu do Índio, 2012.

MAUSS, Marcel. As técnicas corporais. In: Sociologia e antropologia. São Paulo: EPU/EDUSP, 1974. p. 209-234.

MCCALLUM, Cecília. Aquisição de gênero e habilidades produtivas: o caso Kaxinawá. Estudos Feministas, Florianópolis, n. 1 e 2, v. 7, 1999.

. Nota sobre as categorias "gênero" e "sexualidade" e os povos indígenas.
Cadernos Pagu [online]. n. 41, p. 53-61, 2013. Disponível em: http://www.scielo.br/scielo.php?pid=S0104-83332013000200006\&script=sci_arttext . Acesso em: 22 jun. 2014.

MCCLINTOCK, Anne. Couro imperial: raça, gênero e sexualidade no embate colonial. Campinas: Editora da Unicamp, 2010.

MENDES, Cláudio Lúcio. Quem pode resistir à Lara Croft? Você? Estudos Feministas, Florianópolis, n. 16, p. 45-60, 2008.

MINELLA, Luzinette. Temáticas prioritárias no campo de gênero e ciências no Brasil: raça/etnia, uma lacuna? Cadernos Pagu, Campinas, n. 40, p. 95-140, 2013.

NEVES, Delma Pessanha. O consumo de bebidas alcoólicas: prescrições sociais. BIB, São Paulo, n. 55, p. 73-98, 2003.

NIMUENDAJÚ, Curt. Os Apinayé. Belém: Museu Paraense Emílio Goeldi, 1956.

OLIVAR, José. A angústia dos corpos indóceis: prostituição e conflito armado na Colômbia contemporânea. Cadernos Pagu, Campinas, n. 31, p. 965-397, 2008.

OUDSHOORN, Nelly. Beyond the natural body: an archeology of sex hormones. London: Routledge, 1994.

PACHECO DE OLIVEIRA, João. Uma etnologia dos "índios misturados"? Situação colonial, territorialização e fluxos culturais. Mana [online]. v. 4, n. 1, p. 47-77, 1998. Disponível em: $\quad$ http://www.scielo.br/scielo.php?pid=S010493131998000100003\&script=sci_arttext. Acesso em: 06 mai. 2014.

- Infanticídio entre as populações indígenas - Campanha humanitária ou renovação do preconceito? Comissão de Assunto Indígena (CAI) da Associação Brasileira de Antropologia (ABA), 2011. Disponível em: http://www.abant.org.br/ . Acesso em: 20 dez. 2014. 
PARREIRAS, Carolina. Beijos, atos, orgasmos e telas: o sexo em exibição. Cadernos Pagu, Campinas, n. 35, p. 371-378, 2010.

PEREIRA, Edilene Machado; RODRIGUES, Vera. Amor não tem cor?! Gênero e raça/cor na seletividade afetiva de homens e mulheres negros(as) na Bahia e no Rio Grande do Sul. Revista da Associação Brasileira de Pesquisadores/as Negros, v. 1, n. 2, p. 157-181, 2010.

PISCITELLI, Adriana. Re-criando a (categoria) mulher? In: ALGRANTI, Leila (Org.). A prática feminista e o conceito de gênero. Campinas: IFCH-Unicamp, 2002.

POCAHY, Fernando. Entre vapores \& vídeos pornôs: dissidências homo/eróticas na trama discursiva do envelhecimento masculino. Estudos Feministas, Florianópolis, n. 20, p. 357-376, 2012.

PRECIADO, Beatriz. Manifiestocontra-sexual: prácticas subversivas de identidad sexual. Madrid: Opera Prima, 2002.

REICHER, Erica; KOO Kathryn. The body beautiful: symbolism and agency in the social world. Annual Review of Anthropology, n. 33, p. 297-317, 2004.

RIUS, Lourdes. ¿Violencia invisible o del éxtasis al dolor? Estudos Feministas, Florianópolis, n. 16, p. 133-144, 2008.

RODRIGUES, Patrícia. O surgimento das armas de fogo: alteridade e feminilidade entre os Javaé. Estudos Feministas, Florianópolis, v. 7, n. 1 e 2, 1999.

ROHDEN, Fabíola. "O homem é mesmo a sua testosterona": promoção da andropausa e representações sobre sexualidade e envelhecimento no cenário brasileiro. Horizontes Antropológicos, Porto Alegre, n. 35, p. 161-196, 2011.

ROSA, Patricia Carvalho. Romance de primas com primas e o problema dos afetos: parentesco e micropolítica de relacionamentos entre interlocutores tikuna, sudoeste amazônico. Cadernos Pagu [online]. n. 41, 2013. Disponível em: http://www.scielo.br/pdf/cpa/n41/08.pdf . Acesso em: 22 jun. 2014.

ROSA, A. M. "Eu também sou do mato": a produção do corpo e da pessoa entre os Kaingang. In: Povos Indígenas da Bacia Hidrográfica do Lago Guaíba. Porto Alegre: Prefeitura municipal de Porto Alegre, 2008.

RUBIO, Dany Mahecha. Sexualidad y afecto entre los macuna y los nükak, pueblos de la amazonia colombiana. Cadernos Pagu [online]. n. 41, 2013. p. 63-75. Disponível em: http://www.scielo.br/pdf/cpa/n41/07.pdf . Acesso em: 22 jun. 2014

SACCHI, Ângela; GRAMKOW, Márcia (Org.). Gênero e povos indígenas. Rio de Janeiro: Museu do Índio, 2012. 
SAHLINS, Marshall. O "pessimismo sentimental" e a experiência etnográfica: por que a cultura não é um "objeto" em via de extinção (parte I). Mana, Rio de Janeiro, v. 3, n. 1, p. 41-73, 1997.

SALES, Shirlei; PARAÍSO, Marlucy. Juventude ciborgue e a transgressão das fronteiras de gênero. Estudos Feministas, Florianópolis, n. 19, p. 535-548, 2011.

SANT'ANNA, Denise B. Cultos e enigmas do corpo na História. In: STREY, Marlene Neves; CABEDA, Sonia (Org.). Corpos e Subjetividades. Porto Alegre: PUCRGS, 2004. p. 107-131.

SANTOS, Boaventura de Sousa. Para além do pensamento abissal: das linhas globais a uma ecologia dos saberes. In: SANTOS, Boaventura de Sousa; MENESES, Maria Paula. Epistemologias do Sul. São Paulo: Cortez, 2010. p. 31-83.

SANTOS, Emanuelle; SCHOR, Patricia. Brasil, estudos pós-coloniais e contracorrentes análogas: entrevista com Ella Shohat e Robert Stam. Estudos Feministas, Florianópolis, v. 21, n. 2, p. 701-726, 2013.

SCAVONE, Lucila. Estudos de gênero: uma sociologia feminista? Estudos Feministas, Florianópolis, n. 16, p. 173-186, 2008 a.

Políticas Feministas do aborto. Estudos Feministas, Florianópolis, n. 16, p. 675-680, 2008b.

SCOTT, Joan. Gênero: uma categoria útil de análise histórica. Educação e Realidade, Porto Alegre, v. 20, n. 2, p. 71-99, 1995.

SEEGER, Anthony; DAMATTA, Roberto; VIVEIROS DE CASTRO, Eduardo A construção da pessoa nas sociedades indígenas. Boletim do Museu Nacional, Rio de Janeiro, v. 32, n. 1-2, p. 2-19, 1979.

SEGATO, Rita Laura. Las estructuras elementales de la violencia: ensayos sobre género entre la antropología, el psicoanálisis y los derechos humanos. Buenos Aires: Universidad Nacional de Quilmes/Prometeo 3010, 2003.

Gênero e colonialidade: em busca de chaves de leitura e de um vocabulário estratégico descolonial. E-cadernos ces [Online], n. 18, 2012. Disponível em: http://eces.revues.org/1533. Acesso em: 16 abr. 2014.

SILVA, Luís Augusto. Prazer sem camisinha: novos posicionamentos em redes de interação online. Cadernos Pagu, Campinas, n. 35, p. 241-277, 2010.

TEIXEIRA, Flávia. L'Italia dei Divieti: entre o sonho de ser européia e o babado da prostituição. Cadernos Pagu, Campinas, n. 31, p. 275-308, 2008.

VERDUM, Ricardo (Org.). Mulheres Indígenas, Direitos e Políticas Públicas. Brasília: INESC, 2008. p. 21-31. Disponível em: 
http://www.inesc.org.br/biblioteca/publicacoes/outras-publicacoes/LIVRO\%20 MULHERES\%20INDIGENAS1.pdf/view . Acesso em: 14 jan. 2013.

WAGLEY, Charles; GALVÃO, Eduardo. Os índios Tenetehara: uma cultura de transição. Rio de Janeiro: MEC, 1955.

WILLIAMS, Linda. Screening Sex: Revelando e dissimulando o sexo. Cadernos Pagu, Campinas, n. 38, p. 13-51, 2012. 